\title{
Factors responsible for developing common oral antibiotic resistant to urinary tract infection (UTI) among the children
}

\author{
Nirbachita Biswas ${ }^{1}$ and Hamida Khanum ${ }^{2 \star}$ \\ 'Department of Public Health Sciences, New Mexico State University, Las Cruces, New Mexico, USA. \\ ${ }^{2}$ Parasitology Branch, Department of Zoology, University of Dhaka, Dhaka 1000, Bangladesh. \\ ${ }^{*}$ Corresponding author. Email: hamida_khanum@yahoo.com
}

Copyright (C) 2020 Biswas and Khanum. This article remains permanently open access under the terms of the Creative Commons Attribution License 4.0, which permits unrestricted use, distribution, and reproduction in any medium, provided the original work is properly cited.

Received 18th August, 2020; Accepted 22nd September, 2020

\begin{abstract}
The present study is designed to access the factors responsible for developing recurring infection and antibiotic resistance among children with urinary tract infection (UTI). The socio-demographic characteristics of the respondents are important to determine the level of awareness regarding antibiotic resistance; $16.1 \%$ children were between 1 to 5 years of age, $21.9 \%$ between 5.1 to 9 years, $29.9 \%$ between 9.1 to 12 years and $32.1 \%$ between 12.1 to 15 years of age who were suffering from UTI. Out of 137 children, $17.5 \%$ males were suffering from UTI and the rest $82.5 \%$ were females; it reveals that $34.3 \%$ children intakes less than $500 \mathrm{ml}$ of water every day while $40.1 \%$ intakes 500 to $1000 \mathrm{ml}$ of water, $21.1 \%$ children take about 1000 to $1500 \mathrm{ml}$ of water and only $4.4 \%$ intakes more than $1500 \mathrm{ml}$ of water every day. The present investigation showed that $50.4 \%$ of the children had a history of taking antibiotics while $29.9 \%$ did not know whether the child had a history of taking antibiotics and $5.8 \%$ has no history of taking antibiotic. Out of the 81 children who received treatment for UTI, $76.5 \%$ were fully cured after receiving antibiotic while $19.8 \%$ were not cured after taking antibiotic. Out of the 43 children who took the antibiotic on time, $79 \%$ took it for 1 to 3 days, $16.3 \%$ took it for 3 to 5 days and $4.7 \%$ took it for 5 to 7 days. Positive correlation found with male children, maintaining toilet hygiene and recurrent UTI.54.4\% respondent used water to maintain the child's toilet hygiene suffered from recurrent UTI and $92.8 \%$ respondent used other means excluding water to maintain the child's toilet hygiene suffered from recurrent UTI $(p<0.05)$. The major factors for developing recurrent UTI and resistance to certain antibiotics are taking medicine from pharmacy, doing self-prescription, incomplete medication courses along with lack of hygiene and insufficient water intake. There should be rational use of antibiotic and culture sensitivity for urine should be a mandatory test before administering antibiotics for UTI. There is need to build awareness about antibiotic resistance through health campaigns.
\end{abstract}

Keywords: Antibiotic, resistance, children, toilet hygiene, UTI, water intake.

\section{INTRODUCTION}

Bacterial infections resistant to antibiotics can limit the availability of effective treatment options, rendering some commonly encountered bacterial infections difficult to treat, including those of the urinary tract (Kahlmeter, 2000). The changing pattern of antibiotic resistance in the causative microorganism of urinary tract infection (UTI) in children is a growing problem, as it is an important cause of morbidity in childhood (Talan et al., 2000). UTI is caused as an inflammatory response of urothelium to the invading pathogenic organisms (Gupta et al., 1999; Nazme, et al., 2017). Worldwide, about 150 million people are being diagnosed with UTI every year (Phillips et al., 2000). UTIs are associated with increased morbidity and mortality and it is one of the commonest nosocomial infections (Prats et al., 2000). The symptoms of UTI include fever, dysuria, urinary urgency and cloudy urine (Foxman et al., 2000b). It is estimated that $3 \%$ of girl's and $1 \%$ of the boy's experience at least one episode of UTI before 11 years of age (Phillips et al., 2000).

Escherichia coli (E. coli) is the commonest organism causing UTI. E. coli belongs to the family Enterobactericeae and accounts for 75 to $90 \%$ of all UTI in 
inpatients and outpatients (Hooton and Stamm, 1997; Rustom et al., 2020). Reports reveal that $E$. coli is the most common cause of UTI and antibiotic resistance is reported to be high among the strains (Gupta et al., 1999; Foxman, 2002). UTI is initiated by $E$. coli, which is a commensal in the gastrointestinal tract (Foxman et al., 2000a; Hooton and Stamm, 1997). Antimicrobial resistance (AMR) is an internationally recognized threat to health and antibiotic resistance is one of the important issues to think about. The contribution of primary healthcare to induce antibiotic resistance is particularly important as this is where almost $80 \%$ of all antibiotics used within the health service are prescribed (Foxman et al., 2000b). According to the guidelines of Infectious Diseases Society of America (IDSA) the recommended drug for treatment of UTI is Trimethoprim/ Sulphamethoxazole where the resistance prevalence is $<10$ to $20 \%$. Ciprofloxacin is recommended where the resistance is $>20 \%$ (Foxman et al., 2000b). Early treatment with an appropriate and effective antibiotic is essential for prevention of long-term complications (Supplemental Tables, 2000).

Generally, up to $95 \%$ of the cases with severe symptoms are treated without bacteriological investigations (Wayne, 2000). Infectious diseases are major health problems in Bangladesh requiring frequent use of antimicrobials. Infection with resistant bacteria was first reported over more than 60 years ago (Sharples and Lloyd, 1990). Antibiotic resistant infections are also twice as likely to be associated with greater morbidity and mortality and are associated with increased healthcare costs (Hulton et al., 1991). Children receive a disproportionately high number of antibiotics compared with middle aged populations (Hulton et al., 1991). Young children are more vulnerable to immediate and long-term complications, including renal scarring and renal failure (Versalovic et al., 1991; Ahmed and Swedlund 1998; Foxman et al., 2000b; Bakker et al. 2004).

The emergence of antibiotic resistance in the management of UTIs is a serious public health issue, particularly in the developing countries, including Bangladesh. Bacterial resistance to antibiotics complicates the treatment of UTI and the antibiotic sensitivity pattern shows geographical variations (Supplemental Tables, 2000).

The microbial etiology of urinary infections has been regarded as well-established and reasonably consistent. Escherichia coli remains the predominant uropathogen $(80 \%)$ isolated in acute community-acquired uncomplicated infections, followed by Staphylococcus saprophyticus (10 to $15 \%$ ). Klebsiella, Enterobacter, and Proteus species and Enterococci infrequently cause uncomplicated cystitis. The etiology of UTI is also affected by underlying host factors such as age, diabetes, spinal cord injury, or catheterization that complicate UTI. Etiologic pathogens associated with UTI among patients with diabetes include Klebsiella spp., Group B streptococci, and Enterococcus spp., as well as E. coli. Other common uropathogen include Pseudomonas and Proteus mirabilis (Daschner and Marget, 1975; Ronald, 2002; Yüksel et al., 2006).
The extensive use of antibiotics in the community and hospitals has fueled this crisis. Mechanisms such as antibiotic control programs, better hygiene, and synthesis of agents with improved antimicrobial activity need to be adopted in order to limit bacterial resistance ( $\mathrm{Neu}, 1992$; Ladhani and Gransden, 2003; Lutter et al., 2005; Sood and Gupta, 2012).

According to OECD (Organization for Economic Cooperation and Development) in the more developed countries antibiotics are obtained mostly only by prescription, whereas in "developing" non-OECD countries like Bangladesh many antibiotics (Nahar et al., 2006; Khanum et al., 2012) including those commonly used to treat urinary tract infection, can be obtained over the counter, without the need for a prescription (Wayne, 2000; Sharples and Lloyd, 1990; Hulton et al., 1991; Versalovic et al., 1991; Versalovic et al., 1994). The study is designed to assess the risk factors for developing antibiotic resistant UTI among children and this may help to prevent the irrational use of antibiotics in children (Simmering et al., 2017).

\section{MATERIALSAND METHODS}

A cross sectional study was carried out in Dhaka Shishu Hospital, Sher-E-Bangla Nagor, Dhaka. The study was conducted during January 2018 to June 2018. Attendants of child patient (137) aged 1 to 15 years with UTI who came for treatment in Dhaka Shishu Hospital, Agarga, Dhaka. For sample collection, clean catch, midstream urine samples (MSU) were collected in sterile, wide mouthed, universal containers from the patients clinically suspected to have UTI.

After collection, the specimens were immediately transported to the laboratory and processed within two hours of the collection. Quantitative un-spun wet mount microscopic examination was done for the well mixed uncentrifuged urine sample. $50 \mu$ l of urine sample was placed on clean grease free glass slide and covered with 20 $\mathrm{mm} \times 20 \mathrm{~mm}$ coverslip and was examined under high power field of microscope for the presence of pus cells. The cut off for the significant finding was 1 pus cell / 7 high power fields (hpfs) (Colleen et al., 2003). Data was checked for the completeness and consistency on daily basis after data collection and entered in SPSS, MS-Excel, Epi-info was used. Data was analyzed in order to measure/assess the specific objective(s). The percentage, frequency, mean, median S.D was measured and for association, chi-Square was used.

\section{RESULTS}

In the present study, out of 137 children, $16.1 \%$ children were between 1 to 5 years of age, $21.9 \%$ between 5.1 to 9 years, $29.9 \%$ between 9.1 to 12 years and $32.1 \%$ between 12.1 to 15 years of age who were suffering from UTI. Here, 
$17.5 \%$ children suffering from UTI were males and the rest $82.5 \%$ were females. Study shows that $40.1 \%$ of the child's mother completed primary level education, 20.4\% completed secondary level education, $5.8 \%$ completed graduation, $1.5 \%$ completed post-graduation and $32.1 \%$ had no formal education.

Regarding the profession of the fathers, $48.9 \%$ of the child's father does not have any formal education, $21.9 \%$ completed higher secondary level, $16.8 \%$ completed their graduation, $5.1 \%$ completed post graduate and $7.3 \%$ completed primary level of education. Whereas, it was found that $40.1 \%$ of the child's mother completed primary level education, $20.4 \%$ secondary, $5.8 \%$ were graduate, $1.5 \%$ post-graduate and $32.1 \%$ had no formal education. Among all the respondents, $33.6 \%$ belonged to lower class, $37.2 \%$ lower middle class, $23.4 \%$ middle class and $5.8 \%$ upper class. In this study, $40.9 \%$ of the child's mother was housewives, $19.0 \%$ were service holders and $40.1 \%$ belonged to other professions.

Present study reveals that $34.3 \%$ children intakes less than $500 \mathrm{ml}$ of water every day while $40.1 \%$ intakes 500 to $1000 \mathrm{ml}$ of water. $21.1 \%$ children take about 1000 to 1500 $\mathrm{ml}$ of water and only $4.4 \%$ intakes more than $1500 \mathrm{ml}$ of water every day (Table 1). Study shows that $52,6 \%$ children voids 5 to 6 times a day and $29.9 \%$ voids 4 to 5 times a day. $13.1 \%$ voids 3 to 4 times a day while $4.4 \%$ voids 2 to 3 times a day. $49.6 \%$ children maintain toilet hygiene by using water, $9.5 \%$ tissue paper, $24.8 \%$ diaper and $16.1 \%$ uses other forms to maintain toilet hygiene (Table 2).

The present investigation study found that $78.1 \%$ of the children had history of hospital admission while, $5.1 \%$ did not have any history of hospital admission; $20.4 \%$ of the respondents did not know if the child had any history of hospital admission (Table 3). Out of the 102 children who had a history of hospital stay, $64 \%$ stayed in hospital as they were ordered by the doctor, $17 \%$ stayed in hospital as the health condition of the child worsened while $19 \%$ stayed in hospital as there was no positive change with previous medication (Figure 1).

The present study shows that $50.4 \%$ of the children had a history of taking antibiotics while $29.9 \%$ did not know whether the child had a history of taking antibiotics and $5.8 \%$ has no history of taking antibiotic. This study shows that, out of the 69 children who received antibiotics (Table 4); $72.5 \%$ got the medication from pharmacy while $24.6 \%$ got it from free samples. About $58 \%$ of the children took the antibiotics on time and $37.7 \%$ did not take the antibiotic on time. Out of the 43 children who took the antibiotic on time, $79 \%$ took it for 1 to 3 days, $16.3 \%$ took it for 3 to 5 days and $4.7 \%$ took it for 5 to 7 days (Table 5 ).

Out of the 69 children who had a history of antibiotic intake, $11.6 \%$ could name Ciprofloxacin as the antibiotic they gave the child to take and $10.1 \%$ could name Azithromycin. A majority of $78.3 \%$ could not state the name of the antibiotic they gave their child to take (Table 6). Also, $12 \%$ were suggested by family to take antibiotic, $10 \%$ were suggested by doctor, $62 \%$ were suggested by pharmacy
Table 1. Distribution of respondents according to the amount of water intake by the child.

\begin{tabular}{lcc}
\hline $\begin{array}{l}\text { Amount of water intake } \\
\text { by the child }\end{array}$ & Frequency & Percentage \\
\hline$<500 \mathrm{ml}$ & 47 & 34.3 \\
$500-1000 \mathrm{ml}$ & 55 & 40.1 \\
$1000-1500 \mathrm{ml}$ & 29 & 21.1 \\
$>1500 \mathrm{ml}$ & 6 & 4.4 \\
Total & 137 & 100 \\
\hline
\end{tabular}

Table 2. Distribution of respondents according to how the child maintains toilet hygiene.

\begin{tabular}{lcc}
\hline $\begin{array}{l}\text { How the child maintains } \\
\text { toilet hygiene? }\end{array}$ & Frequency & Percentage \\
\hline Using water & 68 & 49.6 \\
Using Tissue & 13 & 9.5 \\
Diaper & 34 & 24.8 \\
Others & 22 & 16.1 \\
Total & 137 & 100 \\
\hline
\end{tabular}

Table 3. Distribution of respondents according to any history of hospital admission.

\begin{tabular}{lcc}
\hline $\begin{array}{l}\text { History of hospital } \\
\text { admission }\end{array}$ & Frequency & Percentage \\
\hline Yes & 102 & 78.1 \\
No & 7 & 5.1 \\
Do not know & 28 & 20.4 \\
Total & 137 & 100 \\
\hline
\end{tabular}

Table 4. Distribution of respondents according to history of taking antibiotic.

\begin{tabular}{lcc}
\hline $\begin{array}{l}\text { Any history of } \\
\text { taking antibiotic }\end{array}$ & Frequency & Percentage \\
\hline Yes & 69 & 50.4 \\
No & 8 & 5.8 \\
Do not know & 41 & 29.9 \\
Total & 137 & 100 \\
\hline
\end{tabular}

and $16 \%$ followed previous prescription (Figure 2).

The present investigation reveals that $73.7 \%$ of the children were previously diagnosed with UTI while, $16.8 \%$ were not diagnosed with UTI previously. Table 7 shows that out of the 101 children who previously got diagnosed with UTI, $80.2 \%$ got treatment while $10.9 \%$ did not receive any treatment. Study shows that $50.6 \%$ of the respondents have a tendency to start the previous antibiotic without further advice while $49.4 \%$ do not have the tendency.

The study reveals that $86.4 \%$ respondent who were 


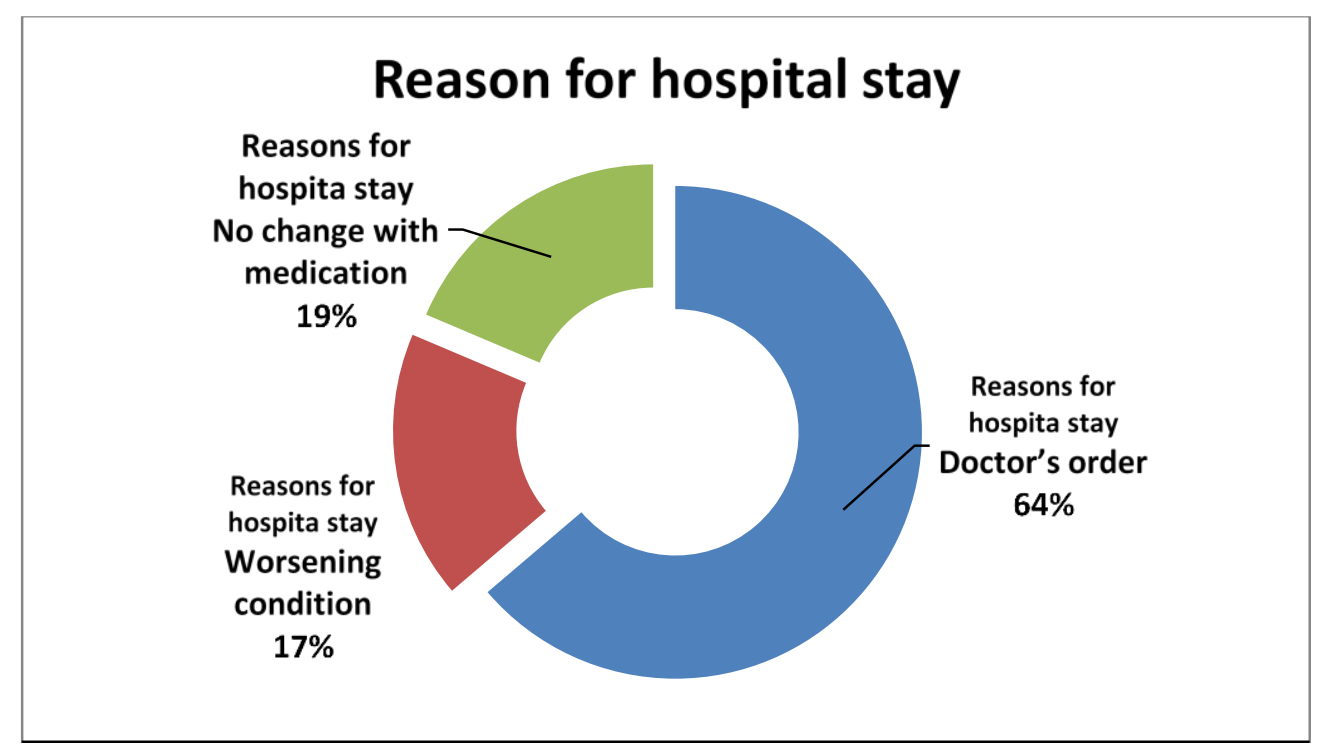

Figure. 1. Distribution of history of hospital stay of the children affected by UTI.

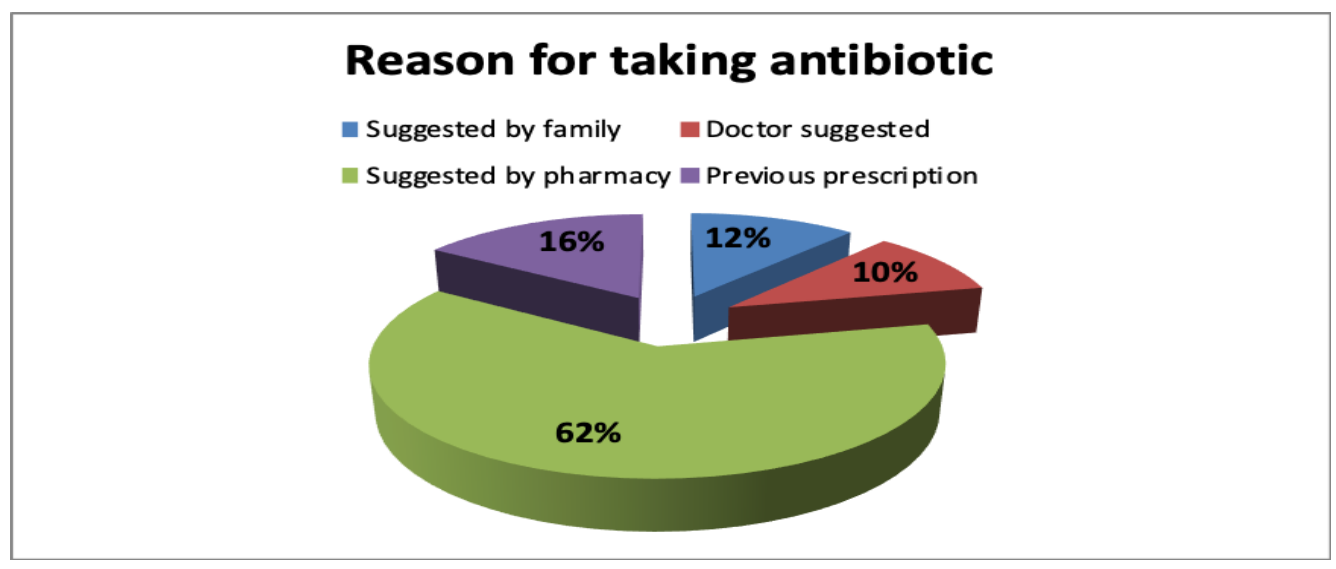

Figure 2. Distribution of respondents according to urine culture sensitivity.

Table 5. Distribution of respondents according to the length the respondent continued the treatment.

\begin{tabular}{lcc}
\hline $\begin{array}{l}\text { How long the respondent } \\
\text { continues the antibiotic }\end{array}$ & Frequency & Percentage \\
\hline 1-3 days & 35 & 79.0 \\
3-5 days & 6 & 16.3 \\
5-7 days & 2 & 4.7 \\
Total & 43 & 100 \\
\hline
\end{tabular}

females suffered from recurrent UTI and $22.2 \%$ respondent who were male had recurrent UTI $(p<0.05)$. Therefore, there was statistical significant relationship between gender and recurrent UTI. The relative risk was 3.886 and attributable risk was 0.641 (Table 8).

The present observation reveals that $88.6 \%$ respon-
Table. 6. Distribution of respondents according to the name of the antibiotic used.

\begin{tabular}{lcc}
\hline Name of the antibiotic & Frequency & Percentage \\
\hline Ciprofloxacin & 8 & 11.6 \\
Azithromycin & 7 & 10.1 \\
Do not know the name & 54 & 78.3 \\
Total & 69 & 100 \\
\hline
\end{tabular}

dents who were illiterate had their child suffering from recurrent UTI and $66.7 \%$ respondents who were literate had their child suffering from recurrent UTI $(p<0.05)$. Therefore, there was statistically significant relationship between educational status of the mother and recurrent UTI. The relative risk was 1.330 and attributable risk was 0.220 (Table 9). 
Table 7. Distribution of respondents according to past history of UTI.

\begin{tabular}{lcc}
\hline respondent was diagnosed with & Frequency & Percentage \\
\hline UTI previously & 101 & 73.7 \\
Yes & 23 & 16.8 \\
No & 13 & 9.5 \\
Do not know & 137 & 100 \\
Total & & \\
\hline
\end{tabular}

Table 8. Relationship between gender of child and the recurrent UTI.

\begin{tabular}{|c|c|c|c|c|c|c|c|c|}
\hline \multirow{2}{*}{ Gender } & & \multicolumn{2}{|c|}{ Recurrent UTI } & \multirow{2}{*}{ Total } & \multirow{2}{*}{$\begin{array}{c}\text { Chi } \\
\text { square }\end{array}$} & \multirow{2}{*}{ P Value } & \multirow{2}{*}{$\begin{array}{c}\text { Relative } \\
\text { risk }\end{array}$} & \multirow{2}{*}{$\begin{array}{l}\text { Attributable } \\
\text { risk }\end{array}$} \\
\hline & & Present & Absent & & & & & \\
\hline \multirow{2}{*}{ Female } & $\mathrm{N}$ & 95 & 15 & 110 & \multirow{6}{*}{46.039} & \multirow{6}{*}{0.0010} & \multirow{6}{*}{3.886} & \multirow{6}{*}{0.641} \\
\hline & $\%$ & 86.4 & 13.6 & $100 \%$ & & & & \\
\hline \multirow{2}{*}{ Male } & $\mathrm{N}$ & 6 & 21 & 27 & & & & \\
\hline & $\%$ & 22.2 & 77.8 & $100 \%$ & & & & \\
\hline \multirow{2}{*}{ Total } & $\mathrm{N}$ & 101 & 36 & 137 & & & & \\
\hline & $\%$ & 73.7 & 26.3 & $100 \%$ & & & & \\
\hline
\end{tabular}

Table 9. Relationship between educational status of the mother and recurrent UTI.

\begin{tabular}{|c|c|c|c|c|c|c|c|c|}
\hline \multirow{2}{*}{\multicolumn{2}{|c|}{$\begin{array}{l}\text { Educational status of } \\
\text { mother }\end{array}$}} & \multicolumn{3}{|c|}{ Recurrent UTI } & \multirow[t]{3}{*}{ Chi square } & \multirow[t]{3}{*}{ P-value } & \multirow{2}{*}{$\begin{array}{c}\text { Relative } \\
\text { risk }\end{array}$} & \multirow{2}{*}{$\begin{array}{l}\text { Attributable } \\
\text { Risk }\end{array}$} \\
\hline & & \multirow{2}{*}{$\begin{array}{c}\text { Present } \\
39\end{array}$} & \multirow{2}{*}{$\begin{array}{c}\text { Absent } \\
5\end{array}$} & \multirow{2}{*}{\begin{tabular}{|c|} 
Total \\
44
\end{tabular}} & & & & \\
\hline Illiterate & $\mathrm{N}$ & & & & & & & \\
\hline & $\%$ & 88.6 & 11.4 & $100 \%$ & & & & \\
\hline \multirow[t]{2}{*}{ Literate } & $\mathrm{N}$ & 62 & 31 & 93 & 7.442 & 0.0010 & 1.330 & 0.220 \\
\hline & $\%$ & 66.7 & 33.3 & $100 \%$ & & & & \\
\hline \multirow[t]{2}{*}{ Total } & $\mathrm{N}$ & 101 & 36 & 137 & & & & \\
\hline & $\%$ & 73.7 & 26.3 & $100 \%$ & & & & \\
\hline
\end{tabular}

The present investigation reveals that $54.4 \%$ respondent used water to maintain the child's toilet hygiene suffered from recurrent UTI and $92.8 \%$ respondent used other means excluding water to maintain the child's toilet hygiene suffered from recurrent UTI $(p<0.05)$. Therefore, there was statistically significant relationship between gender and recurrent UTI. The relative risk was 0.587 and attributable risk was -0.383 (Table 12).

\section{DISCUSSION}

\section{Factors for recurrent UTI}

In the study, $34.3 \%$ children intakes less than $500 \mathrm{ml}$ of water every day while $40.1 \%$ intakes 500 to $1000 \mathrm{ml}$ of water. $21.1 \%$ children take about 1000 to $1500 \mathrm{ml}$ of water and only $4.4 \%$ intakes more than $1500 \mathrm{ml}$ of water every day (Table 1). About $49.6 \%$ children maintain toilet hygiene by using water, $9.5 \%$ uses tissue paper, $24.8 \%$ uses diaper and $16.1 \%$ uses other forms to maintain toilet hygiene (Table 2). And it is evident in many studies that these are causes or risk factors of recurrent UTI (Prakash and Saxena, 2013; Shaikh et al., 2008).

\section{Antibiotic}

In the present investigation, $50.4 \%$ of the children had a history of taking antibiotics while $29.9 \%$ did not know whether the child had a history of taking antibiotics. Out of 69 children who had a history of antibiotic intake, $11.6 \%$ could name ciprofloxacin as the antibiotic they gave the child to take and $10.1 \%$ could name Azithromycin. A majority of $78.3 \%$ could not state the name of the antibiotic they gave their child to take. Out of the 43 children who took the antibiotic on time, $79 \%$ took it for 1 to 3 days, $16.3 \%$ took it for 3 to 5 days and $4.7 \%$ took it for 5 to 7 days. The children $(73.7 \%)$ were previously diagnosed with UTI and $16.8 \%$ were not diagnosed with UTI previously (Table 8 ). Table 10 suggests that out of the 81 children who received treatment for UTI, $76.5 \%$ were fully 
Table 10. Distribution of respondents according to whether the patient fully cured after receiving the antibiotic.

\begin{tabular}{lcc}
\hline $\begin{array}{l}\text { Was the patient fully cured after } \\
\text { receiving the antibiotic }\end{array}$ & Frequency & Percentage \\
\hline Yes & 62 & 76.5 \\
No & 16 & 19.8 \\
Do not know & 3 & 3.7 \\
Total & 81 & 100 \\
\hline
\end{tabular}

Table 11. Distribution of respondents according to urine culture antibiotics sensitivity.

\begin{tabular}{lcccc}
\hline \multirow{2}{*}{ Urine culture } & \multicolumn{2}{c}{ Sensitive } & \multicolumn{2}{c}{ Resistant } \\
\cline { 2 - 5 } & Frequency & Percentage & Frequency & Percentage \\
\hline Ampicillin & 45 & 63.3 & 23 & 32.4 \\
Cephalexin & 34 & 47.9 & 12 & 16.9 \\
Ceftazidime & 56 & 78.9 & 4 & 5.6 \\
Cefixime & 61 & 85.9 & 10 & 14.1 \\
Amikacin & 66 & 93.0 & 5 & 7.0 \\
Ciprofloxacin & 50 & 70.4 & 12 & 16.9 \\
Cotrimoxazole & 54 & 76.1 & 8 & 11.2 \\
Piperacillin & 67 & 94.4 & 2 & 2.8 \\
Cefepime & 70 & 98.6 & 2 & 2.8 \\
Gentamicin & 44 & 62.0 & 7 & 9.9 \\
Netilmicin & 65 & 91.5 & 6 & 8.5 \\
Nalidixic acid & 62 & 87.3 & 4 & 5.6 \\
Nitrofurantoin & 50 & 70.4 & 13 & 18.3 \\
Total & 71 & 100 & 71 & 100 \\
\hline
\end{tabular}

cured after receiving antibiotic while $19.8 \%$ were not cured after taking antibiotic (Table 10).

Study showed that out of 71 children who had urine culture sensitivity test, $32.4 \%$ are resistant to ampicillin, $16.9 \%$ to cephalexin, $5.6 \%$ to ceftazidime, $14.1 \%$ to cefixime, $7 \%$ to amikacin, $16.9 \%$ to ciprofloxacin, $11.2 \%$ to cotrimoxazole, $2.8 \%$ to piperacillin, $2.8 \%$ to cefepime, $9.9 \%$ to gentamicin, $8.5 \%$ to netilmidin, $5.6 \%$ to nalidixic acid and $18.3 \%$ to nitrofurantoin (Table 11 ).

Table 12 reveals that $54.4 \%$ respondent used water to maintain the child's toilet hygiene suffered from recurrent UTI and $92.8 \%$ respondent used other means excluding water to maintain the child's toilet hygiene suffered from recurrent $\mathrm{UTI}(\mathrm{p}<0.05)$. Therefore, there was statistical significant relationship between gender and recurrent UTI. The relative risk was 0.587 and attributable risk was 0.383 .

The present observation explains that the correlation between gender and mode of toilet hygiene with recurrent UTI is strong. Whereas the strength of the correlation is moderate between recurrent UTI with educational status of mother and amount of water intake (Table 13).

A previous study in a mixed population of children with UTIs demonstrated that history of UTI as a risk factor for increased antibiotic resistance. Other studies have shown that urinary malformations, history of urinary catheter, hospitalization within the last year, and recent treatment with antibiotics are additional risk factors for resistant organisms (Colleen et al., 2003) which are similar as the present study. Previous pediatric studies found higher sensitivity to Ceftazidime (Colleen et al., 2003) but present study found highest Amikacin 93\% sensitive.

Out of the 101 children who previously got diagnosed with UTI, $80.2 \%$ got treatment while $10.9 \%$ did not receive any treatment. It was observed that there is a wide array of resistance to antibiotics. This might be accountable to the irrational use of such medicines and self-medications (Geerlings, 2016; Foxman, 2010).

\section{Association, relative risk and attributable risk}

About $86.4 \%$ respondent who were females suffered from recurrent UTI and 22.2\% (Table 8). Respondent who were male had recurrent UTI $(p<0.05)$. Therefore, the relationship between gender and recurrent UTI was statistically significant. The relative risk was 3.886 and attributable risk was 0.641 . The present result correlates with the study by Johnson and O'Bryan (2000) on improved repetitive-element PCR fingerprinting for 
Table 12. Relationship between mode of water use for toilet hygiene and the recurrent UTI.

\begin{tabular}{|c|c|c|c|c|c|c|c|c|}
\hline \multirow{2}{*}{\multicolumn{2}{|c|}{$\begin{array}{l}\text { Mode of toilet } \\
\text { hygiene }\end{array}$}} & \multicolumn{2}{|c|}{ Recurrent UTI } & \multirow{3}{*}{$\begin{array}{c}\text { Total } \\
68\end{array}$} & \multirow{2}{*}{$\begin{array}{c}\text { Chi } \\
\text { square }\end{array}$} & \multirow{2}{*}{$P$ Value } & \multirow{2}{*}{$\begin{array}{c}\text { Relative } \\
\text { risk }\end{array}$} & \multirow{2}{*}{$\begin{array}{c}\text { Attributable } \\
\text { risk }\end{array}$} \\
\hline & & Present & Absent & & & & & \\
\hline \multirow{2}{*}{ Water } & $\mathrm{N}$ & 37 & 31 & & & \multirow{6}{*}{0.0010} & \multirow{6}{*}{0.587} & \multirow{6}{*}{-0.383} \\
\hline & $\%$ & 54.4 & 45.6 & $100 \%$ & \multirow{5}{*}{25.990} & & & \\
\hline \multirow{2}{*}{ Non water } & $\mathrm{N}$ & 64 & 5 & 69 & & & & \\
\hline & $\%$ & 92.8 & 7.2 & $100 \%$ & & & & \\
\hline \multirow{2}{*}{ Total } & $\mathrm{N}$ & 101 & 36 & 137 & & & & \\
\hline & $\%$ & 73.7 & 26.3 & $100 \%$ & & & & \\
\hline
\end{tabular}

Table 13. Correlation coefficient with recurrent UTI and the strength of the relationship.

\begin{tabular}{lcc}
\hline Parameters & $\begin{array}{c}\text { Correlation co-efficient with } \\
\text { recurrent UTI ( } \mathbf{r} \text { Value) }\end{array}$ & Strength of relationship \\
\hline Gender & 0.7 & Strong \\
Educational status of mother & -0.3 & Moderate \\
Amount of daily water intake & -0.5 & Moderate \\
Mode of toilet hygiene & 0.6 & Strong \\
\hline
\end{tabular}

resolving pathogenic and nonpathogenic phylogenetic groups within Escherichia coli, where it states that short urethra, close proximity of female urethral meatus to anus influence higher prevalence of UTI in women. Among males, UTI caused by E. coli was high in younger age group of 0 to 9 years, as uncircumcised boys have higher risk (Nahar et al., 2006; Islam et al., 2010).

From the study, $54.4 \%$ respondent used water to maintain the child's toilet hygiene suffered recurrent and $92.8 \%$ respondent used other means excluding water to maintain the child's toilet hygiene suffered from recurrent UTI $(p<0.05) \quad($ Table 12). Therefore, the relationship between mode of toilet hygiene and recurrent UTI was statistically significant. The relative risk was 0.587 and attributable risk was -0.383 .

Therefore, there were statistically significant relationship between gender, mode of toilet hygiene, amount of daily intake of water, educational status of the mother and recurrent UTI. About $50.6 \%$ of the respondents have a tendency to start the previous antibiotic without further advice while $49.4 \%$ do not have the tendency. All these are factors for developing recurrent UTI and resistance to certain antibiotics (Prakash and Saxena, 2013; Singh and Bijoylakshmi, 2016).

The source for the drugs such as antibiotic is questionable as the patients or their attendants seem to get it mostly from pharmacies without any prescription or doctors order which is evident from this study. Even when people are taking these antibiotics, they are not using it for the appropriate time duration as well (Nahar et al., 2006; Islam et al., 2010) . There is need to build awareness about antibiotic resistance through health campaigns and there should be rational use of antibiotic in all sectors of healthcare (Pardeshi, 2018; Flores-Mireles et al., 2015).

\section{Conclusion and recommendation}

It can conclude that, lack of awareness about going to specialist doctors for UTI treatment and taking medicine from pharmacy and doing self-prescription and medication along with lack of hygiene and water intake remains the major factors for recurrent UTI among children. All these are factors for developing recurrent UTI and resistance to certain antibiotics. There is need to build awareness about antibiotic resistance through health campaigns and there should be rational use of antibiotic in all sectors of healthcare. Culture sensitivity for urine should be a mandatory test before administering antibiotics for UTI. Proper counseling should be done to patients about the use of antibiotics. Shopkeepers and pharmacies should not be allowed to prescribe antibiotics on their own without doctor's prescriptions.

\section{CONFLICT OF INTEREST}

The authors declare that they have no conflict of interest

\section{ACKNOWLEDGEMENT}

We like to express our sincere, deepest and heartfelt gratitude to the Faculty of Arts and Social Science, Public Health Department, American International UniversityBangladesh, permitted and supported me to conduct this research for my MPH courses. Permission was taken from the Ethical Committee at American International University Bangladesh.

\section{REFERENCES}

Ahmed, S. M., \& Swedlund, S. K. (1998). Evaluation and treat- 
ment of urinary tract infections in children. American Family Physician, 57(7), 1573-1580.

Bakker, E., van Gool, J., van Sprundel, M., van der Auwera, J. C., \& Wyndaele, J. J. (2004). Risk factors for recurrent urinary tract infection in 4,332 Belgian schoolchildren aged between 10 and 14 years. European Journal of Pediatrics, 163(4-5), 234-238.

Collee, G., Duguid, P., Fraser, G., \& Marmian, P. M. (2003). MacCartney's Practical Medical Microbiology. Churchill Livingstone Publishers, Longman Singapore.

Daschner, F., \& Marget, W. (1975). Treatment of recurrent urinary tract infection in children: Compliance of parents and children with antibiotic therapy regimen. Acta Pædiatrica, 64(1), 105-108.

Flores-Mireles, A. L., Walker, J. N., Caparon, M., \& Hultgren, S. J. (2015). Urinary tract infections: epidemiology, mechanisms of infection and treatment options. Nature reviews microbiology, 13(5), 269-284.

Foxman, B. (2002). Epidemiology of urinary tract infections: incidence, morbidity, and economic costs. The American Journal of Medicine, 113(1), 5-13.

Foxman, B. (2010). The epidemiology of urinary tract infection. Nature Reviews Urology, 7(12), 653-660.

Foxman, B., Barlow, R., D'Arcy, H., Gillespie, B., \& Sobel, J. D. (2000a). Urinary tract infection: self-reported incidence and associated costs. Annals of Epidemiology, 10(8), 509-515.

Foxman, B., Gillespie, B., Koopman, J., Zhang, L., Palin, K., Tallman, P., Marsh, J. V., Spear, S., Sobel, J. D., Marty, M. J., \& Marrs, C. F. (2000b). Risk factors for second urinary tract infection among college women. American journal of epidemiology, 151(12), 1194-1205.

Geerlings, S. E. (2017). Clinical presentations and epidemiology of urinary tract infections. Urinary Tract Infections: Molecular Pathogenesis and Clinical Management, 27-40.

Gupta, K., Scholes, D., \& Stamm, W. E. (1999). Increasing prevalence of antimicrobial resistance among uropathogens causing acute uncomplicated cystitis in women. JAMA, 281(8), 736-738.

Hooton, T. M., \& Stamm, W. E. (1997). Diagnosis and treatment of uncomplicated urinary tract infection. Infectious Disease Clinics, 11(3), 551-581.

Hulton, C. S. J., Higgins, C. F., \& Sharp, P. M. (1991). ERIC sequences: a novel family of repetitive elements in the genomes of Escherichia coli, Salmonella typhimurium and other enterobacteria. Molecular microbiology, 5(4), 825-834.

Islam, M. N., Khaleque, M. A., Siddika, M., \& Hossain, M. A. (2010). Urinary tract infection in children in a tertiary level hospital in bangladesh. Mymensingh Medical Journal, 19(4), 482-486.

Johnson, J. R., \& O'bryan, T. T. (2000). Improved RepetitiveElement PCR Fingerprinting for Resolving Pathogenic and Nonpathogenic Phylogenetic Groups within Escherichia coli. Clinical and Diagnostic Laboratory Immunology, 7(2), 265-273.

Kahlmeter, G. (2000). The ECO - SENS Project: a prospective, multinational, multicentre epidemiological survey of the prevalence and antimicrobial susceptibility of urinary tract pathogens-interim report. Journal of Antimicrobial Chemotherapy, 46(suppl_1), 15-22.

Khanum, H., Munir, F., Shafiullah, A. Z. M., \& Muznebin, F. (2012). Prevalence and comparative likelihood of urinary tract infection (UTI) among female out patients in BSMMU. Bangladesh Journal of Zoology, 40(2), 231-239.

Ladhani, S., \& Gransden, W. (2003). Increasing antibiotic resistance among urinary tract isolates. Archives of Disease in Childhood, 88(5), 444-445.

Lutter, S. A., Currie, M. L., Mitz, L. B., \& Greenbaum, L. A. (2005). Antibiotic resistance patterns in children hospitalized for urinary tract infections. Archives of Pediatrics \& Adolescent medicine, 159(10), 924-928.

Nahar, S. J., Khanum, H., \& Farhana, R. (2006). Occurrence of Escherichia coli infection among the children of Dhaka city. Bangladesh Journal of Zoology, 34(2), 181.

Nazme, N. I., Al Amin, A., Jalil, F., Sultana, J., \& Fatema, N. N. (2017). Bacteriological profile of urinary tract infection in children of a tertiary care hospital. Bangladesh Journal of Child Health, 41(2), 77-83.

Neu, H. C. (1992). The crisis in antibiotic resistance. Science, 257(5073), 1064-1073.

Pardeshi, P. (2018). Prevalence of urinary tract infections and current scenario of antibiotic susceptibility pattern of bacteria causing UTI. Indian Journal of Microbiology Research, 5(3), 334-338.

Phillips, I., King, A., Rowe, B., Eykyn, S., Gransden, W. R., Frost, J., \& Gross, R. (1988). Epidemic multiresistant Escherichia coli infection in West Lambeth health district. The Lancet, 331(8593), 1038-1041.

Prakash, D., \& Saxena, R. S. (2013). Distribution and antimicrobial susceptibility pattern of bacterial pathogens causing urinary tract infection in urban community of meerut city, India. International Scholarly Research Notices Microbiology 2013, 749629.

Prats, G., Navarro, F., Mirelis, B., Dalmau, D., Margall, N., Coll, P., Stell, A., \& Johnson, J. R. (2000). Escherichia coli serotype O15: K52: $\mathrm{H} 1$ as a uropathogenic clone. Journal of Clinical Microbiology, 38(1), 201-209.

Ronald, A. (2002). The etiology of urinary tract infection: traditional and emerging pathogens. The American Journal of Medicine, 113(1), 14-19.

Rustom, S., Zaman, R. F., Barua, P., \& Khanum, H. (2020). occurrence of urinary tract infection among the outpatients of ibn sina diagnostic and imaging center in Dhaka, Bangladesh. Bangladesh Journal of Zoology (Unpublished: Accepted stage).

Shaikh, N., Morone, N. E., Bost, J. E., \& Farrell, M. H. (2008). Prevalence of urinary tract infection in childhood: a metaanalysis. The Pediatric Infectious Disease Journal, 27(4), 302308.

Sharples, G. J., \& Lloyd, R. G. (1990). A novel repeated DNA sequence located in the intergenic regions of bacterial chromosomes. Nucleic Acids Research, 18(22), 6503-6508.

Simmering, J. E., Tang, F., Cavanaugh, J. E., Polgreen, L. A., \& Polgreen, P. M. (2017, January). The increase in hospitalizations for urinary tract infections and the associated costs in the United States, 1998-2011. In Open Forum Infectious Diseases (Vol. 4, No. 1). Oxford University Press.

Singh, R. K., Dewasy, B., Mallick, R. L., \& Kafle, T. K. (2016). Prevalence of antibiotic sensitivity pattern of uropathogens in patients of different age-groups from western region of Nepal. International Journal of Medical Research and Health Sciences, 5(9), 1-7.

Sood, S., \& Gupta, R. (2012). Antibiotic resistance pattern of community acquired uropathogens at a tertiary care hospital in Jaipur, Rajasthan. Indian journal of community medicine: official publication of Indian Association of Preventive \& Social Medicine, 37(1), 39-44.

Supplemental Tables: disk diffusion. NCCLS document M100S10 (2000). Wayne, Pa.: National Committee for Clinical 
Laboratory Standards. Pp. 14-18.

Talan, D. A., Stamm, W. E., Hooton, T. M., Moran, G. J., Burke, T., Iravani, A., Reuning-Scherer, J., \& Church, D. A. (2000). Comparison of ciprofloxacin (7 days) and trimethoprimsulfamethoxazole (14 days) for acute uncomplicated pyelonephritis in women: A randomized trial. JAMA, 283(12), 1583-1590.

Versalovic, J., Koeuth, T., \& Lupski, R. (1991). Distribution of repetitive DNA sequences in eubacteria and application to finerpriting of bacterial enomes. Nucleic Acids Research, 19(24), 6823-6831.

Versalovic, J., Schneider, M., De Bruijn, F. J., \& Lupski, J. R. (1994). Genomic fingerprinting of bacteria using repetitive sequence-based polymerase chain reaction. Methods in Molecular and Cellular Biology, 5(1), 25-40.
Wayne, P. A. (2000). Performance standards for antimicrobial disk susceptibility tests. NCCLS document M2-A7: National Committee for Clinical Laboratory Standards. Pp. 1-18.

Yüksel, S., Öztürk, B., Kavaz, A., Özçakar, Z. B., Acar, B., Güriz, H., Aysev, D., Ekim, M., \& Yalçınkaya, F. (2006). Antibiotic resistance of urinary tract pathogens and evaluation of empirical treatment in Turkish children with urinary tract infections. International Journal of Antimicrobial Agents, 28(5), 413-416. 